\title{
Health belief model concept on the prevention of coronavirus disease-19 using path analysis in West Nusa Tenggara, Indonesia
}

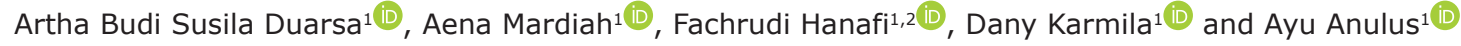 \\ 1. Faculty of Medicine, Al-Azhar Islamic University, Mataram, West Nusa Tenggara, Indonesia; 2. Health Polytechnics of \\ Ministry of Health, Mataram, West Nusa Tenggara, Indonesia. \\ Corresponding author: Artha Budi Susila Duarsa, e-mail: arthasusiladuarsa@gmail.com \\ Co-authors: AM: aenamardiah1@gmail.com, FH: fachrudihanafi1@gmail.com, DK: danykarmila1@gmail.com, \\ AA: anulusayu@gmail.com \\ Received: 01-11-2020, Accepted: 15-01-2021, Published online: 26-02-2021
}

doi: www.doi.org/10.14202/IJOH.2021.31-36 How to cite this article: Duarsa ABS, Mardiah A, Hanafi F, Karmila D, Anulus A (2021) Health belief model concept on the prevention of coronavirus disease-19 using Path analysis in West Nusa Tenggara, Indonesia, Int. J. One Health, 7(1): 31-36.

\begin{abstract}
Background and Aim: Effective prevention of coronavirus disease (COVID-19) requires public health focus on challenges at the community level. This study aimed to identify the determinants of COVID-19 preventive behavior among people in West Nusa Tenggara, Indonesia, using the health belief model.

Materials and Methods: This was a cross-sectional study conducted in West Nusa Tenggara Province, Indonesia. The study sample included 385 randomly selected individuals. The dependent variable was COVID-19 preventive behavior. The data were collected by a questionnaire and analyzed by path analysis using Stata Statistical Software version 13 for Windows 64 bit.

Results: COVID-19 preventive behavior was positively and directly associated with perceived benefits $(b=0.20$; confidence interval [CI] 95\% 0.11-0.29; $p<0.001)$, perceived barriers $(b=-0.15 ; C I 95 \%-0.24-0.06 ; p=0.002)$, and biological sex $(b=-0.43$; CI $05 \%-0.78-0.08 ; p=0.016)$. Preventive behavior was also positively and directly associated with attitude $(b=0.48$; CI 95\% $-0.20-1.16 ; p=0.167)$ and perceived susceptibility $(b=0.06$; CI 95\% $-0.01-0.12 ; p=0.083)$, though these associations were not significant. Preventive behavior was indirectly associated with knowledge, perceived severity, age, health facility availability, and regulation exposure.
\end{abstract}

Conclusion: COVID-19 preventive behavior among people in West Nusa Tenggara, Indonesia, is directly related to the perceived benefits, biological sex, perceived barriers, attitude, and perceived susceptibility. Preventive behavior of COVID-19 is indirectly associated with knowledge, perceived severity, age, health facility availability, and exposure to regulation.

Keywords: coronavirus disease-19, health belief model, path analysis, West Nusa Tenggara.

\section{Introduction}

A previously unidentified viral infection was detected in a small local fish and wild animal market in the city of Wuhan, China's Hubei Province, over the last week of December 2019 [1]. The virus spread rapidly throughout mainland China and became a global pandemic $[2,3]$.

Outbreak response readiness is slow in many countries. Of the 45 low-income countries that undertook a national preparedness assessment, none were considered ready to respond, making them particularly vulnerable to outbreaks. There are many explanations for this, including inadequate nutrition and health, compounded by high rates of human immunodeficiency virus and tuberculosis [4]. Indonesia reported 180,646 coronavirus disease (COVID)positive cases as of September 2, ranking third in Asia

Copyright: Duarsa, et al. This article is an open access article distributed under the terms of the Creative Commons Attribution 4.0 International License (http://creativecommons.org/licenses/ by/4.0/), which permits unrestricted use, distribution, and reproduction in any medium, provided you give appropriate credit to the original author(s) and the source, provide a link to the Creative Commons license, and indicate if changes were made. The Creative Commons Public Domain Dedication waiver (http:// creativecommons.org/ publicdomain/zero/1.0/) applies to the data made available in this article, unless otherwise stated. and $19^{\text {th }}$ globally in terms of death rate [5]. In West Nusa Tenggara Province, a total of 2799 cases have been reported [6].

Individuals with an elevated risk of severe COVID-19 disease and those living with them should consider their risk level before choosing to leave their homes and take steps to protect themselves [7].

Countries are currently in the race through a series of strong evidence-based medicine to get a vaccine that is effective in preventing Covid-19. The Indonesian government has made efforts to fulfill the need for vaccines, including through the purchase of vaccines from Sinovac, Novavax, AstraZeneca, Pfizer, as well as through COVAX / GAVI, as legally stated in Minister of Health Decree No. HK.01.07 / Menkes / 12758/2020 dated 28 December 2020. Prevention and management of this pandemic remain the best ways to cope with the disease and reduce its spread, including following guidelines for prevention and personal hygiene, such as frequent hand washing with soap and water, covering the mouth and nose while coughing and sneezing, and not touching the nose, mouth, and eyes. Every person is critical to promoting health, but individual beliefs, values, preferences, and habits drive right or wrong behavior [8]. 
The WHO proposed a global plan of action designed to reduce the spread of COVID-19 infections. The strategy stresses the importance of following a variety of healthy habits, including, for example, regular washing of hands, maintaining social distance, improving respiratory hygiene, and self-isolation while feeling unwell. However, the WHOs advice is constrained by the fact that it does not focus on recognizing the mechanisms of action underpinning these preventive behaviors or improving individuals' ability to implement them [9].

Implementation of healthy lifestyle practices and disease avoidance requires that the right behaviors be learned and adopted by individuals and society. The Health Belief Model (HBM) is the first theory related to health behavior and can explain prevention behavior and individual disease response. The HBM has provided a useful framework for investigating health behaviors and identifying fundamental health beliefs and has been used to predict a range of health behaviors with moderate success [10].

The HBM provides a framework for explaining one's perceptions and attitudes regarding disease and the negative consequences of poor decision-making. The theory suggests that individuals' assumptions about the risk of contracting a disease or health condition, their understanding of the proposed preventive intervention's efficacy, and signs of action determine the probability of intervention [11].

It is essential to reach various specific populations so that challenges to preventing the spread of COVID-19 disease can be identified and solutions mobilized appropriately at all levels of society. This study employed the HBM to identify determinants of COVID-19 preventive behavior among people in West Nusa Tenggara, Indonesia.

\section{Materials and Methods}

\section{Ethical approval}

Research ethics in this study include approval sheets, anonymity, confidentiality, and ethical feasibility. Ethical feasibility in this study came from the Health Research Ethics Committee in the Faculty of Medicine of Al-Azhar Islamic University (18/EC/ FK-06/UNIZAR/V/2020).

\section{Study design, location and period}

This cross-sectional survey study was conducted in West Nusa Tenggara Province of Indonesia, from May to June 2020. A total of 10 cities/districts were selected to be a part of this study.

\section{Population and sample}

The population of West Nusa Tenggara Province was 5,125,600 people at the time of the study. A sample of 385 people of reproductive age (15-64 years) was selected using simple random sampling calculated using OpenEpi with 5\% standard error. Subjects were recruited through an online social media platform (WhatsApp). Participants had to be aged 15-64 years (productive age) to consent to participate in the study and have access to the internet to be eligible for inclusion. The respondents were presented with an outline of the report's objectives and criteria followed by the consent form and, finally, the survey. Participation was voluntary, and informed consent was required to complete and return the questionnaire. The ethics committee approved the consent protocol since the survey was confidential and non-invasive.

\section{Study variables}

The independent variables were biological sex, age, attitude, knowledge, perceived susceptibility, perceived benefits, perceived barriers, perceived severity, availability of health facility, and exposure to regulation. The dependent variable was COVID-19 prevention behavior.

\section{Definitions}

Biological sex was defined as the respondent's biological characteristics (male or female).

Attitude was defined as a positive or negative view and assessment of the COVID-19 pandemic.

Knowledge was defined as a condition of knowledge regarding COVID-19 gained through experience or association.

Perceived susceptibility was defined as the respondent's subjective perception of the risk of acquiring COVID-19.

Perceived benefit was defined as the respondent's motives for performing a behavior and adopting COVID-19 prevention behavior.

Perceived barrier was defined as the respondent's estimation of obstacles to a specified behavior regarding the COVID-19 pandemic.

Perceived severity was defined as the negative effects a respondent associates with the COVID-19 pandemic.

Availability of health facilities was defined as the existence of accessible health facilities that provide preventive, curative, and rehabilitative care for COVID-19.

Exposure to regulation was defined as the respondent's comprehension of policy regarding COVID-19 distributed by the local and national government.

COVID-19 prevention behavior was defined as the respondent's activities carried out to prevent COVID-19.

\section{Measures}

The instrument was developed using standardized WHO guidelines and adapted to refer to preventive behaviors in COVID-19. Questions were presented in Bahasa Indonesia, a commonly used and widely spoken language in Indonesia.

\section{Statistical analysis}

Descriptive statistics and path analysis were generated using STATA (ver. 13). Path analysis was generalized to evaluate the relationships between biological sex, age, attitude, knowledge, perceived susceptibility, 
perceived benefits, perceived barriers, perceived severity, health facility availability, exposure to regulation, and COVID-19 prevention behavior.

\section{Results}

\section{Sample characteristics}

Table-1 shows the demographic characteristics of the 385 study subjects. Most participants were $\geq 48$ years old $(298 / 385,77.40 \%)$. The majority of study subjects were male $(210 / 385,54.55 \%)$. A total of 338 people $(87.79 \%)$ stated that a health facility was available to them, 321 people $(83.38 \%)$ had been exposed to regulations regarding the prevention of COVID-19, 327 people (84.94\%) had positive perceived susceptibility, $354(91.95 \%)$ had positive perceived severity, 258 (92.99\%) had positive perceived benefits, $343(89.09 \%)$ had positive perceived barriers, $372(96.62 \%)$ had a high degree of knowledge about COVID-19 prevention, 359 (93.25\%) people had positive attitudes toward COVID-19 prevention, and $283(73.51 \%)$ exhibited positive behavior related to COVID-19 prevention.

\section{Path analysis}

The specification of the model defined the correlation between the studied variables. In this analysis, 11 variables were observed. The degree of freedom (df) was $45(\mathrm{df} \geq 0)$, indicating that the path analysis was feasible. The model specification will explain the impact of the variables to be examined. The structural model of path analysis on determinants of coronavirus disease-19 preventive behavior using the health belief model can be seen in Figure-1.

Table- 2 shows the path analysis of the determinants of COVID-19 preventive behavior using the HBM model. COVID-19 preventive behavior was directly affected by attitude, perceived susceptibility, perceived benefits, perceived barriers, and biological sex.
The direct and positive effects of this were attitude on COVID-19 preventive behavior. People with the right attitude had a log odd of 0.48 units higher $(b=0.48$; confidence interval $[\mathrm{CI}] 95 \%-0.20-1.16$; $\mathrm{p}=0.167$ ) than people with a poor attitude, but the difference was not statistically significant. The direct and positive effects were the effect of perceived susceptibility on COVID-19 preventive behavior. People with high perceived susceptibility had a $\log$ odd of 0.06 units higher $(b=0.06$; CI 95\% $-0.01-0.12 ; \mathrm{p}=0.083)$ than people with low perceived susceptibility, but the difference was not statistically significant. The direct and positive effects of this were perceived benefits on COVID-19 preventive behavior. People with high perceived benefits had a log odd of 0.20 units higher $(b=0.20$; CI 95\% 0.11-0.29; $p<0.001)$ than the people with low perceived benefits, a statistically significant difference. There was a direct and negative effect of perceived barriers on COVID-19 preventive behavior. People with high perceived barriers had a log odd of 0.15 units lower $(b=-0.15$; CI $95 \%-0.24-0.06$; $\mathrm{p}=0.002$ ) than people with low perceived barriers, a statistically significant difference. There was a direct and negative effect of biological sex on COVID-19 preventive behavior. Males had a log odd of 0.43 units lower $(b=-0.43$; CI $05 \%-0.78-0.08 ; p=0.016)$ than females, a statistically significant difference.

The results show that COVID-19 preventive behavior was indirectly affected by knowledge, perceived severity, age, health facility availability, and exposure to regulation. Knowledge and perceived severity were positively related to attitude. People with high knowledge $(b=0.04$; CI 95\% 0.02-0.06; $\mathrm{p}=0.001)$ and high perceived severity $(\mathrm{b}=0.01 ; \mathrm{CI} 95 \%$ $0.01-0.03 ; p=0.006$ ) had a more positive attitude. Age was positively correlated with perceived susceptibility. People over 48 years of age had increased perceived

Table-1: Characteristic of participants (categorical data).

\begin{tabular}{|c|c|c|c|c|}
\hline No. & Variables & Criteria & Frequency (n) & Percentage \\
\hline 1. & Age & $\begin{array}{l}<48 \text { years } \\
\geq 48 \text { years }\end{array}$ & $\begin{array}{c}87 \\
298\end{array}$ & $\begin{array}{l}22.60 \\
77.40\end{array}$ \\
\hline 2. & Biological sex & $\begin{array}{l}\text { Male } \\
\text { Female }\end{array}$ & $\begin{array}{l}210 \\
175\end{array}$ & $\begin{array}{l}54.55 \\
45.45\end{array}$ \\
\hline 3. & Health facility & $\begin{array}{l}\text { Not available } \\
\text { Available }\end{array}$ & $\begin{array}{c}47 \\
338\end{array}$ & $\begin{array}{l}12.21 \\
87.79\end{array}$ \\
\hline 4. & Exposure to regulation & $\begin{array}{l}\text { Not exposed } \\
\text { Exposed }\end{array}$ & $\begin{array}{c}64 \\
321\end{array}$ & $\begin{array}{l}16.62 \\
83.38\end{array}$ \\
\hline 5. & Perceived susceptibility & $\begin{array}{l}\text { Negative } \\
\text { Positive }\end{array}$ & $\begin{array}{c}58 \\
327\end{array}$ & $\begin{array}{l}15.06 \\
84.94\end{array}$ \\
\hline 6. & Perceived severity & $\begin{array}{l}\text { Negative } \\
\text { Positive }\end{array}$ & $\begin{array}{c}31 \\
354\end{array}$ & $\begin{array}{c}8.05 \\
91.95\end{array}$ \\
\hline 7. & Perceived benefits & $\begin{array}{l}\text { Negative } \\
\text { Positive }\end{array}$ & $\begin{array}{c}27 \\
258\end{array}$ & $\begin{array}{c}7.01 \\
92.99\end{array}$ \\
\hline 8. & Perceived barriers & $\begin{array}{l}\text { Negative } \\
\text { Positive }\end{array}$ & $\begin{array}{c}42 \\
343\end{array}$ & $\begin{array}{l}10.91 \\
89.09\end{array}$ \\
\hline 9. & Knowledge & $\begin{array}{l}\text { Low } \\
\text { High }\end{array}$ & $\begin{array}{c}13 \\
372\end{array}$ & $\begin{array}{c}3.38 \\
96.62\end{array}$ \\
\hline 10. & Attitude & $\begin{array}{l}\text { Negative } \\
\text { Positive }\end{array}$ & $\begin{array}{c}26 \\
359\end{array}$ & $\begin{array}{c}6.75 \\
93.25\end{array}$ \\
\hline 11. & COVID-19 prevention behavior & $\begin{array}{l}\text { Negative } \\
\text { Positive }\end{array}$ & $\begin{array}{l}102 \\
283\end{array}$ & $\begin{array}{l}26.49 \\
73.51\end{array}$ \\
\hline
\end{tabular}




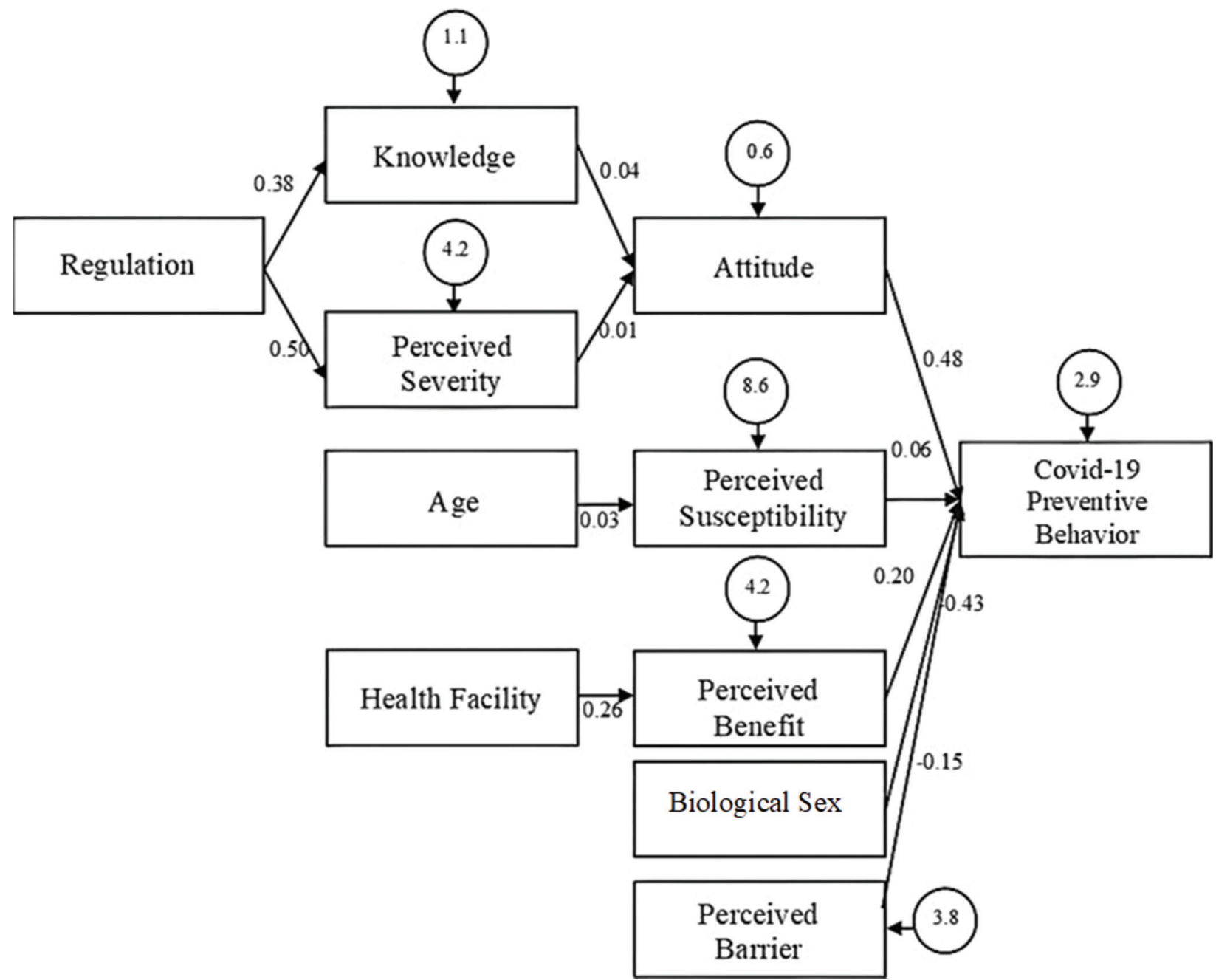

Figure-1: Structural model of path analysis on determinants of coronavirus disease-19 preventive behavior using the health belief model.

Table-2: Results of path analysis on determinants of coronavirus disease-19 preventive behavior using the health belief model.

\begin{tabular}{|c|c|c|c|c|c|c|}
\hline \multirow[t]{2}{*}{ Dependent variable } & & \multirow[t]{2}{*}{ Independent variable } & \multirow[t]{2}{*}{ b } & \multicolumn{2}{|c|}{$95 \% \mathrm{CI}$} & \multirow[t]{2}{*}{ p-value } \\
\hline & & & & Lower limit & Upper limit & \\
\hline \multicolumn{7}{|l|}{ Direct effect } \\
\hline \multirow[t]{5}{*}{ COVID-19 preventive behavior } & $\leftarrow$ & Attitude (positive) & 0.48 & -0.20 & 1.16 & 0.167 \\
\hline & $\leftarrow$ & $\begin{array}{l}\text { Perceived } \\
\text { susceptibility (high) }\end{array}$ & 0.06 & -0.01 & 0.12 & 0.083 \\
\hline & $\leftarrow$ & Perceived benefits (high) & 0.20 & 0.11 & 0.29 & $<0.001$ \\
\hline & $\leftarrow$ & Perceived barriers (high) & -0.15 & -0.24 & -0.06 & 0.002 \\
\hline & $\leftarrow$ & Biological sex (Male) & -0.43 & -0.78 & -0.08 & 0.016 \\
\hline \multicolumn{7}{|l|}{ Indirect effect } \\
\hline \multirow{2}{*}{ Attitude (positive) } & $\leftarrow$ & Knowledge (high) & 0.04 & 0.02 & 0.06 & 0.001 \\
\hline & $\leftarrow$ & Perceived severity (high) & 0.01 & 0.01 & 0.03 & 0.006 \\
\hline Perceived susceptibility (high) & $\leftarrow$ & Age (years) & 0.03 & 0.01 & 0.06 & 0.009 \\
\hline Perceived benefits (high) & $\leftarrow$ & $\begin{array}{l}\text { Availability on health } \\
\text { facility }\end{array}$ & 0.26 & 0.11 & 0.41 & 0.001 \\
\hline Knowledge (high) & $\leftarrow$ & Exposure to regulation & 0.38 & 0.24 & 0.52 & $<0.001$ \\
\hline Perceived severity (high) & $\leftarrow$ & Exposure to regulation & 0.50 & 0.22 & 0.78 & 0.001 \\
\hline $\begin{array}{l}\text { Number of total respondents }=385 \\
\text { Log likelihood }=-1529.49\end{array}$ & & & & & & \\
\hline
\end{tabular}

susceptibility $(b=0.03$; CI 95\% 0.01-0.06; $p=0.009)$. The availability of health facilities was positively related to perceived benefits. Availability of health facilities increased perceived benefits $(b=0.26$; CI
$95 \% 0.11-0.41 ; \mathrm{p}=0.001)$. Exposure to regulation was positively related to knowledge and perceived severity. Exposure to regulation increased knowledge $(b=0.38$; CI 95\% 0.24-0.52; $\mathrm{p}<0.001)$ and perceived severity. 


\section{Discussion}

This study is the first of its kind in Indonesia, West Nusa Tenggara Province, to use the HBM to identify determinants of COVID-19 preventive behavior using path analysis. The results of this study indicate that COVID-19 preventive behavior was directly affected by attitude, perceived susceptibility, perceived benefits, perceived barriers, and biological sex.

A meta-analysis examined the influence of factors present when an attitude was formed to the degree this attitude guides future behavior - in this case, COVID-19 preventive behavior. Results indicated that when they were easy to remember (accessible) and stable over time, attitudes correlated more strongly with future behavior. Because of increased accessibility attitudes, future behavior was predicted more strongly when participants directly experienced the object of attitude and often reported their attitudes [12].

Perceived susceptibility refers to the subjective risk assessment of COVID-19. Someone who feels at low risk for a disease is more likely to engage in unhealthy behavior. In contrast, someone who feels at risk for a disease is more likely to take actions to reduce that risk [13]. The HBM predicts that a person who has perceived susceptibility to an illness tends to prevent the disease from occurring. In contrast, someone with low perceived vulnerability to illness has a lower tendency to take action to prevent the disease from occurring. Individuals are more likely to engage in unhealthy conduct or risky conduct when their perceived risk is low [14].

If an individual believes that specific actions will reduce susceptibility to COVID-19 or reduce the seriousness of the disease, they tend to engage in behavior, regardless of objective facts about the behavior's effectiveness. Indeed, the HBM theory states that health-related behavior is also influenced by the perceived benefits of a person taking healthy actions or behaviors, that is, COVID-19 preventive behavior. A person's perceived benefits will impact their preventive action [14]. The perceived benefits can affect one's decision to act or take measures to minimize harm. If anyone believes in behavior that can reduce a disease's susceptibility, they appear to be interested [13].

In general, females are more resistant to infection than males, which may be mediated by multiple factors, including sex hormones and high expression of coronavirus receptors (ACE 2) in males and lifestyle, such as higher levels of smoking and drinking among males compared to females. Furthermore, females tend to take more responsibility for COVID19 prevention than males, such as regular hand washing, face mask wearing, and ordering goods to be delivered rather than shopping abroad [15].

This study also shows that COVID-19 preventive behavior was indirectly affected by knowledge, perceived severity, age, health facility availability, and regulation exposure. Good knowledge of COVID-19 may not necessarily imply good, sustainable behavior to prevent COVID-19. On the other hand, a lack of knowledge may also not necessarily imply poor environmental practice. Therefore, it is necessary to consider other factors that intervene in the behavior [16].

Here, perceived severity refers to the subjective estimation of the seriousness of COVID-19 and the risk that could be induced if it is not treated or avoided. Anyone who agrees that a disease is severe would have a higher chance of taking steps to avoid or minimize its impact [14]. The perceived severity of the disease can affect the belief in the illness. Trust in one's abilities is the secret to influence improvements in health behavior [17].

Age directly affected perceived severity, primarily because older individuals feel more threatened by the intensity, and deterioration associated with COVID-19. In general, the risk of getting severely ill from COVID-19 increases with age. Indeed, 8 out of 10 COVID-19-related deaths reported in the United States have been among adults aged 65 years and older [7].

For prevention of health problems, the individual should first feel personally susceptible (perceive susceptibility), be able to predict the possible seriousness of the disease (perceived severity), believe in the benefits of practicing prescribed health habits (perceived benefits), and be able to resolve the costs of practicing that particular behavior (perceived barriers) [18].

This study highlighted the importance of attitude and biological sex (female) in contributing to behavior in prevention. Interestingly, this behavior did not encourage perceived vulnerability. Similarly, an HBM analysis found that perceived susceptibility has more accurately predicted preventive behavior than sick-role behavior [19]. A related study showed that people should try to change these four perceptions (perceived barriers, benefits, severity, and susceptibility) for the greatest behavioral impact to prevent COVID-19 [20].

The limitations of our study include the online nature of data collection. The sample may not be truly representative of the targeted population. However, the study was conducted when Indonesia was under large-scale social restrictions, and the only plausible approach was online data collection. The questionnaire should be tested in different populations to assess its generalizability, and the data were self-reported. Therefore, the actual results reported could be overestimated.

\section{Conclusion}

COVID-19 preventive behavior among people in West Nusa Tenggara, Indonesia, is directly affected by perceived benefits, biological sex, perceived barriers, attitude, and perceived susceptibility, and was indirectly affected by knowledge, perceived severity, age, availability of health facility, and exposure to regulation. Our findings are likely to be useful in developing future prevention programs. For various activities to 
be included in HBM preventive programs on COVID19 , more research may be needed.

\section{Authors' Contributions}

ABSD: Designed the research study, conceptualization, and writing. AM: Sample collection and data analysis. FH and DK: Interpreted the results and constructed the discussion. AA: Analyzed the data and prepared the manuscript. All authors read and approved the final manuscript.

\section{Acknowledgments}

This research was supported and financed by Al-Azhar Islamic University, Mataram, West Nusa Tenggara, Indonesia, with grant number 04/RISET/FK UNIZAR/V/2020. The authors are grateful to the people in West Nusa Tenggara who helped and willing to join as the study subjects who have participated in this study.

\section{Competing Interests} interests.

The authors declare that they have no competing

\section{Publisher's Note}

Veterinary World (Publisher of International Journal of One Health) remains neutral with regard to jurisdictional claims in published institutional affiliation.

\section{References}

1. Akintunde, E. (2017) Theories and Concepts for Human Behavior in Environmental Preservation. J. Environ. Sci. Public Health, 1(2): 120-133.

2. Li, Q., Guan, X. and Wu, P. (2020) Early transmission dynamics in Wuhan, China, of novel coronavirus-infected pneumonia. N. Engl. J. Med., 382(13): 1199-1207.

3. Chen, N., Zhou, M. and Dong, X. (2020) Epidemiological and clinical characteristics of 99 cases of 2019 novel coronavirus pneumonia in Wuhan, China: A descriptive study. Lancet., 395(10223): 507-513.

4. Whitworth, J. (2020) COVID-19: A fast evolving pandemic Trans. R. Soc. Trop. Med. Hyg., 114(4): 227-228.

5. Worldometer. (2020) Coronavirus Cases. Worldometer. Available from: https://www.worldometers.info/coronavirus/?. Retrieved on 03-09-2020.
6. Diskominfotik NTB. (2020) COVID-19 NTB. Diskominfotik NTB. Available from: https://www.corona. ntbprov.go.id. Retrieved on 03-09-2020.

7. CDC. (2020) Older Adults and COVID-19. Centers for Disease Control and Prevention. Available from: https:// www.cdc.gov/coronavirus/2019-ncov/need-extra-precautions/older-adults.html. Retrieved on 04-09-2020.

8. Chan, J.F.W., Yuan, S. and Kok, K.H. (2020) A familial cluster of pneumonia associated with the 2019 novel coronavirus indicating person-to-person transmission: a study of a family cluster. Lancet, 395(10223): 514-523.

9. WHO. (2020) Covid 19 Strategy Update. World Health Organization. Available from: https:/www.who.int/ docs/default-source/coronaviruse/covid-strategy-update-14april2020.pdf?sfvrsn=29da3ba0_19. Retrieved on 03-09-2020.

10. Abraham, C. and Sheeran, P. (2014) The health belief model. In: Cambridge Handbook of Psychology, Health and Medicine, Second Edition. Cambridge University Press, Cambridge. p97-102.

11. Rosenstock, I.M. (1974) The health belief model and preventive health behavior. Health Educ. Monogr., 2(4): 354-386.

12. Glasman, L.R. and Albarracín, D. (2006) Forming attitudes that predict future behavior: A meta-analysis of the attitude-behavior relation. Psychol. Bull., 132(5): 778-822.

13. Onoruoiza, S.I., Musa Phd, A. and Dangani, B. (2015) Using health beliefs model as an intervention to non-compliance with hypertension information among hypertensive patients. IOSR JHSS, 20(9): 11-16.

14. Murti, B. (2018) Prinsip Dan Metode Riset Epidemiologi. Gajah Mada University Press, Jakarta.

15. Bwire, G.M. (2020) Coronavirus: Why are men more vulnerable to covid-19 than women? S N. Compr. Clin. Med., 2: 874-876

16. Lu, H., Stratton, C.W. and Tang, Y.W.W. (2020) Outbreak of pneumonia of unknown etiology in Wuhan, China: The mystery and the miracle. J. Med. Virol., 92(4): 401-402.

17. Shojaei, S., Farhadloo, R., Aein, A. and Vahedian, M. (2016) Effects of the Health Belief Model (HBM)-based educational program on the nutritional knowledge and behaviors of CABG patients. J. Tehran. Univ. Hear. Cent., 11(4): 181-186.

18. Rosenstock, I.M. (1974) Historical origins of the health belief model. Health Educ. Monogr., 2(4): 328-335.

19. Janz, N.K. and Becker, M.H. (1984) The Health Belief Model: A Decade Later. Health Educ. Behav., 11(1): 1-47.

20. Solhi, M., Zadeh, D.S., Seraj, B. and Zadeh, S.F. (2010) The application of the health belief model in oral health education. Iran. J. Public Health, 39(4): 114-119. 